However, in view of the increasing use of solvent-extracted feeding-stuffs and the possible need of ruminants for essential fatty acids, Cunningham \& Loosli (1954) raised the question of whether or not such acids are furnished by the lipids of the rumen bacteria.

Concurrently with studies in which Cunningham \& Loosli (I954) were unable to demonstrate synthesis of linoleic or linolenic acid by bovine rumen bacteria in vitro, Garton \& Oxford (1955) undertook an examination of the lipids present in bacteria of the rumen fluid of mature, hay-fed sheep. The lipids, which accounted for $9 \%$ of the dry weight of the organisms, comprised $39.2 \%$ of acetone-insoluble material (phospholipids) and $48 \cdot 3 \%$ of acetone-soluble lipids, the remainder consisting essentially of free, lower, steam-volatile fatty acids (almost certainly fermentation products). The proportion of acetone-soluble lipids was made up of neutral (glyceride) fat $38 \cdot 2 \%$ and unsaponifiable matter $10.1 \%$; the latter consisted largely of sterol-like material but no cholesterol was detected. The fatty acids of both the glycerides and the phospholipids were fairly saturated, having iodine values of 23.8 and 29.3 respectively; none of the unsaturation in either was due to linoleic or linolenic acids.

Thus it appears that if the ruminant requires essential fatty acids they must be of dietary origin and must also escape saturation in the rumen; that some almost certainly do reach the intestine unaffected by hydrogenation is inferred from the occurrence of cis-cis-linoleic acid in cow's-milk fat (White \& Brown, r949) and the presence in the plasma of pasture-fed cows of cholesterol esters containing considerable amounts of $\mathrm{C}_{18}$ polyethenoid acids, apparently largely as cis-isomers (Lough \& Garton, 1957).

\title{
REFERENCES
}

Cunningham, H. M. \& Loosli, J. K. (1954). 7. Anim. Sci. 13, 265.

Garton, G. A. \& Oxford, A. E. (1955). F. Sci. Fd Agric. 6, 142.

Garton, G. A., Hobson, P. N. \& Lough, A. K. (1958). Nature, Lond., r82, 15 II.

Hartman, L., Shorland, F. B. \& McDonald, I. R. C. (1954). Nature, Lond., 174, I85.

Hilditch, T. P. (1956). The Chemical Constitution of Natural Fats, 3rd ed. revised, p. 152. London: Chapman and Hall Ltd.

Johns, A. T. (1953). N.Z. F. Sci. Tech. 35, sect. A, p. 262.

Lough, A. K. \& Garton, G. A. (1957). Biochem. F. 67, 345.

Reiser, R. (1951). Fed. Proc. 10, 236.

Reiser, R. \& Reddy, H. G. R. (1956). F. Amer. Oil Chem. Soc. 33, 55.

Shorland, F. B. (1944). Nature, Lond., r53, I68.

Shorland, F. B. (1955). In Progress in the Chemistry of Fats and Other Lipids. Vol. 3, chapter 8. [R. T. Holman, W. D. Lundberg and T. Malkin, editors.] London and New York: Pergamon Press.

Shorland, F, B., Weenink, R. O. \& Johns, A. T. (I955). Nature, Lond., I75, i 129.

Shorland, F. B., Weenink, R. O., Johns, A. T. \& McDonald, I. R. C. (I957). Biochem. F. 67, 328.

White, M. F. \& Brown, J. B. (1949). Y. Amer. Oil Chem. Soc. 26, 385.

Ward, R. M. \& Allen, R. S. (1957). F. agric. Fd Chem. 5, 765.

Willey, N. B., Riggs, J. K., Colby, R. W., Butler, O. D. Jr. \& Reiser, R. (1952). J. Anim. Sci. 11, 705.

\section{Milk composition in relation to rumen metabolism}

\section{By J. A. F. Rook, National Institute for Research in Dairying, Shinfield, Reading}

For many years, the view was held that the type and amount of food offered to a cow, though it had a marked effect on milk yield, had a negligible effect on the fat and 
solids-not-fat content of milk, the only recognized exception being the temporary changes in fat content brought about by the giving of certain oilcakes or oils. However, some 20 years ago Powell $(1938,1939,194 \mathrm{I})$ provided convincing evidence that the fine grinding of the entire roughage in a ration, or a considerable reduction in roughage intake and an increase in the concentrate feed, reduced the percentage and yield of fat without affecting total milk production. This specific effect on fat secretion of the amount and physical form of roughage has now been fully confirmed (see Balch, Balch, Bartlett, Cox \& Rowland (1952) for references). Milk of unusually low fat content, observed from time to time with cows grazing young herbage (see McClymont, 1950) and also by members of the National Agricultural Advisory Service with cows fed on kale, concentrates and limited amounts of hay or straw, is also associated with a shortage of roughage in the diet.

Furthermore, Riddet, Campbell, McDowall \& Cox (194I-2a,b) reported a fall in solids-not-fat content as well as a fall in the yield of milk of cows given only half of their normal production ration, and Rowland (I946) demonstrated that rations deficient in either energy or protein reduce the solids-not-fat content of milk. Rations providing energy in excess of normal requirements were later shown to increase the solids-not-fat content of milk, but excess of dietary protein had no effect (Rook, 1953). It is now widely recognized that the plane of energy nutrition of the cow has, in addition to its well-known effect on milk yield, a specific effect on the solids-not-fat content of milk (see review by Burt, 1957). Moreover, the marked increase in the solids-not-fat content of milk which usually follows the beginning of grazing by cattle in the spring is probably the result of an increase in the plane of energy nutrition (Rook \& Rowland, I959).

I propose in this paper to give a brief account of current knowledge on these specific effects of the diet of the cow on the content of fat and solids-not-fat of milk, and to consider them in relation to metabolism in the rumen.

\section{Depression of milk-fat secretion in cattle on rations low in roughages}

(Where specific references are not given, the source of information will be found in the paper by Balch et al. 1952)

Type of ration. A reduction in milk-fat secretion without accompanying changes in milk yield has been produced in cows on rations of $8 \mathrm{lb}$ or less of hay daily (or corresponding amounts of other roughage) and concentrates to normal standards or above, or on rations in which the entire roughage had been ground. Such rations do not always produce the effect. With cattle at pasture, a depression in milk-fat content is observed most frequently on young herbage supplemented with a concentrate food. On dry feeds, the depression in milk-fat secretion is independent of the type and level of protein in the ration (Balch, Balch, Bartlett, Cox, Rowland \& Turner, 1954) but is particularly marked on rations rich in readily soluble carbohydrates, e.g. those containing large amounts of flaked maize (Balch, Balch, Bartlett, Hosking, Johnson, Rowland \& Turner, 1955).

Effect on fat secretion. The extent of the depression in the fat content obtained by different investigators has varied considerably, but the extreme effect has been 
to reduce the fat content to $40 \%$ of the original value. Undoubtedly a large part of the variation is attributable to differences in the experimental rations used, but other factors appear to be involved. Depressions in fat percentage are generally less marked in animals in good condition and in animals in advanced lactation.

A depression in the milk-fat secretion of cows on low-roughage diets has invariably been associated with a change in fat composition. Milk fat in the cow and other ruminants is distinguished from the milk fat of other species, and from animal depot fats in general, by a relatively high content (up to $20 \%$ on a molar basis) of short-chain $\left(\mathrm{C}_{4}-\mathrm{C}_{10}\right)$ acids (Hilditch, 1956), and when a reduction in fat secretion has occurred the proportion of these acids has been correspondingly reduced. Some reduction in the weights of higher saturated acids (largely palmitic and stearic) and also of unsaturated acids (largely oleic) secreted has also been observed.

Physical and biochemical changes in the rumen. Rations low in roughage and rich in flaked maize, with which Balch and his collaborators obtained the most marked depressions in fat secretion, produced characteristic changes in the physical movements of the rumen and in the physical and chemical composition of the digesta (Balch, Balch, Bartlett, Bartrum, Johnson, Rowland \& Turner, 1955). There was a marked reduction in the time spent by an animal in rumination and the rate of reticulum contractions tended to be slower. The rumen level of fill and the dry matter in the rumen were less than normal and the digesta had a slushy consistency. The rate of passage of fibrous materials through the rumen was reduced and the small amount of crude fibre in the ration was badly digested. On such rations, starch digested within the reticulo-rumen accounted for more than half of the total dry matter digested.

The pattern of microbial fermentation in the rumen of the carbohydrate food materials was also quite distinct, probably owing to a change in the types and numbers of micro-organisms present in the rumen. (Masson (195I) has observed characteristic changes in the microflora and microfauna of lambs given rations containing large amounts of flaked maize.) Troughs and peaks of concentration of total volatile fatty acids in the rumen contents were more marked than on normal rations, and at the peak concentration ( $2-3 \mathrm{~h}$ after feeding) transient high levels of lactic acid were found and the $\mathrm{pH}$ of rumen contents dropped to between 4 and 5 . A marked change in the relative proportions of the volatile fatty acids also occurred: acetic acid fell from about 50 to $33 \%$ of the total volatile acids and propionic acid increased from 25 to $38 \%$. These observations conform with those of Phillipson (1952) on lambs fed on rations rich in flaked maize. Rations containing normal quantities of roughage offered in ground form produce similar changes in the products of rumen fermentation (Balch \& Rowland, 1957).

These changes in the end-products of rumen fermentation give rise to changes in the blood levels of total volatile fatty acids and of ketone bodies. McClymont $(195 \mathrm{r} a, b)$ reported values for the arterial blood level of total volatile fatty acids, of $\mathrm{I} \cdot \mathrm{O}-\mathrm{I} \cdot \mathrm{I}$ m-equiv./1., for a cow on a low-roughage diet in which milk-fat secretion was depressed, that are considerably lower than the values of $\mathrm{x} \cdot 3^{-2} \cdot \mathrm{I} \mathrm{m}$-equiv./1. he obtained for cows on normal rations. Since acetic acid usually accounts for some 
$90 \%$ of the total volatile fatty acids in systemic blood, this change probably reflects largely a fall in blood acetic acid. Also Van Soest, Allen \& Maki (1954) observed a $50 \%$ decrease in blood ketone bodies in cows transferred from normal to lowroughage rations.

Effect of specific metabolites. A number of experiments have been reported in which individual volatile fatty acids, or their salts, have been given to cows on lowroughage rations, either mixed with their food or introduced directly into the rumen through a fistula. Addition of sodium acetate (500-1 $500 \mathrm{~g} /$ day), or acetic acid, has frequently produced an almost complete recovery in the fat content of the milk, but individual animals have occasionally failed to show a response. Sodium butyrate, in a single cow to which it was given, increased the percentage of milk fat, but addition of sodium propionate or propionic acid consistently failed to do so (Tyznik \& Allen, 195 I; Balch, Johnson \& Turner, 1955).

The milk fat of cows during starvation shows a change in composition (Smith \& Dastur, 1938) similar to that which occurs on low-roughage diets, but intravenous or intraruminal infusions of acetate to starving animals have consistently failed to cause an increase in the short-chain acids of milk fat (Malpress, 1945-6; Mann \& Shaw, 1947; McClymont, 195 Ib); under such extreme conditions, however, it would be surprising if the provision of a single metabolite produced a response.

In short-term experiments, the feeding of glucose (Knodt, I94I) or glycerol (Vallance \& McClymont, 1959), which both increase the production of propionic acid in the rumen, or the intravenous infusion of glucose (Vallance \& McClymont, 1959) have all been reported to depress milk-fat secretion, and Knodt (194I) observed a concomitant decrease in blood ketone bodies.

Discussion. Milk of unusually low fat content is produced by cows on rations lacking in the physical condition of fibrousness, but not necessarily fibre as such. Digesta within the rumen of a cow typically show a differentiation between a lower layer consisting of an intimate mixture of rumen liquor and small food particles and an upper, firmer layer of the larger and more fibrous food materials. A fall in roughage intake, or a reduction in particle size, leads to a change in the distribution of dry matter between the two phases, a change that is particularly enhanced by a high proportion of readily soluble material in the concentrate food. The more intimate admixture of food materials with rumen liquor favours a rapid fermentation of the soluble food constituents, at the expense of the rate of cellulose digestion and, probably owing to a change in the microflora, leads to a change in the relative proportions of acetic and propionic acids produced within the rumen.

It is this change in the production of acetic and propionic acids that has generally been held to be responsible for the depression in synthesis of milk fat, a point of view that has received considerable support from the knowledge acquired in the past I0-1 5 years (see Folley, 1956; Glascock, I958). Milk fat arises from two main sources: part (estimated at $20-30 \%$ ) is derived from a fraction of the 'neutral fat' of blood plasma which has its origin in dietary fat; the remainder is synthesized within the mammary gland from glycerol, which is itself synthesized from hexose units either in the liver or mammary gland, and from fatty acids of chain length 
$\mathrm{C}_{4}-\mathrm{C}_{16}$ that are synthesized in the mammary gland from acetate and a $\mathrm{C}_{4}$ molecule which is probably $\beta$-hydroxybutyrate. The decrease in the proportion of the shortchain acids in the milk fat of cows in which fat secretion has been depressed suggests a reduction in that part of the milk fat derived from fatty acids synthesized within the mammary gland. This reduction could arise in three ways: from a shortage of acetate (or other metabolites) for oxidation, or from a shortage of acetate or of the $\mathrm{C}_{4}$ molecule for the synthesis of higher fatty acids.

Energy is required for all milk-secretion processes and a large part of this energy is probably derived from the oxidation of acetate within the mammary gland. Since cows on low-roughage diets normally maintain their milk yield and an increase in protein synthesis occasionally occurs concomitantly with the fall in fat content, a shortage of acetate for oxidation is unlikely. One would expect energy derived from oxidation to be equally available for the various synthetic processes. A reduction in the synthesis of fatty acids due to a low concentration of acetate in mammary arterial blood is, however, a distinct possibility and is in line with many of the experimental observations. Such a thesis does, however, imply that oxidative mechanisms within the mammary gland are less sensitive to a shortage of acetate than is the synthesis of fatty acids: the rate of synthesis of fatty acids may vary directly with the concentration of acetate in mammary arterial blood, whereas the rate of oxidation of acetate may be affected only by an absolute shortage of acetate. The third possibility, a shortage of $\beta$-hydroxybutyrate, could arise from the antiketogenic action (see Pennington, 1957) of the increased amounts of propionate produced within the rumen of cows on rations low in 'roughage'. This metabolic pathway would be sensitive to changes in the uptake from the rumen of both acetic and propionic acids, and provides also a possible explanation of the effect of intravenous infusions of glucose on milk-fat secretion (Vallance \& McClymont, 1959).

Any, or all, of these mechanisms could in theory be responsible for the reduced synthesis of fatty acids, but with the knowledge at present available it is impossible to assess their relative importance.

\section{Effect of plane of energy nutrition on the solids-not-fat content of milk}

Evidence for the effect of the plane of energy nutrition of the cow on the solids-notfat content of her milk is now unequivocal. With cows fed according to the standards recommended by Woodman ( 1957 ), additional food providing an increase of $25-50 \%$ in the energy allowance will not normally lead to an increase in solids-not-fat of more than $0.2-0.3$ percentage units (on a value of between about 8.0 and $9.0 \%$ ) but under experimental conditions, with cows moved from a plane of marked underfeeding to one of generous overfeeding, increases of up to 0.8 have been obtained. The effect of additional food is more marked at low than at high levels of feeding, but it is only in part a reflection of the law of diminishing returns. The major non-fatty solids of milk are the sugar, lactose, and the proteins, casein, $\beta$-lactoglobulin and $\alpha$-lactalbumin, and any change in percentage of solids-not-fat with feeding is due largely to a change in protein content which, since casein nitrogen contributes about $80 \%$ of the total nitrogen of milk, is almost quantitatively accounted for by a change in 
the content of casein. The lactose content is not affected by overfeeding, and during underfeeding any fall in lactose is much less than that in casein. During underfeeding, a marked fall in milk yield also occurs and the decrease in lactose is probably related to a reduction in the overall metabolic activity of the mammary gland. The specific effect of plane of energy nutrition on milk composition is thus confined to an effect on protein synthesis.

Milk proteins are synthesized within the mammary gland from plasma amino acids (Barry, 1958) but factors controlling the rate of synthesis are not yet known. Flaked maize, however, is a food of special value in promoting increases in solids-notfat content and this effect cannot be accounted for entirely by its high energy content (in terms of starch equivalent). Balch, Balch, Bartlett, Bartrum et al. (r955) obtained increases of $0.4-0.5$ percentage units in the mean solids-not-fat content of milk of cows changed from a normal ration to one low in fibre and rich in flaked maize, increases that are greater than would have been expected from the resulting improvement in plane of energy nutrition. Propionic acid, the production of which within the rumen is, as previously mentioned, increased on such rations, may have a specific role in relation to the synthesis of milk proteins.

On absorption from the rumen, propionate is metabolized either on its passage through the rumen wall or in the liver and only small quantities are present in systemic blood. It is unlikely, therefore, that propionate is directly involved in the synthesis of milk proteins from amino acids in the mammary gland. In a preliminary investigation, however, I have observed a significant increase of from 1o to $15 \%$ in the plasma amino-acid level of cows changed from typical winter foods to the grazing of spring pasture at the same time as the usual increases in the solids-not-fat content of milk occurred. This finding suggests that the plasma amino-acid level influences synthesis of milk protein and the supply of propionate absorbed from the rumen may thus control the overall degradation and synthesis of amino acids in the liver, and hence the plasma amino-acid level. A possible metabolic pathway is:

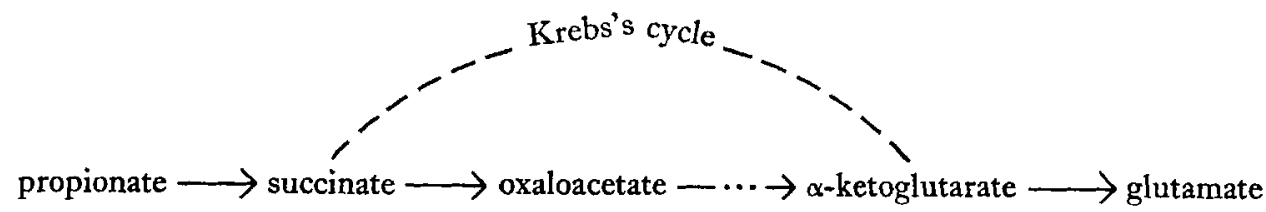

From glutamate, a large number of other non-essential amino acids can be synthesized.

\section{Conclusions}

From this brief survey, it is clear that the conditions under which feeding affects the fat and solids-not-fat contents of milk are now well established and that circumstantial evidence associates such effects with the pattern of production of volatile fatty acids in the rumen. Insufficient evidence is available, however, to establish with certainty the metabolic routes by which the products of fermentation within the rumen affect the secretion of milk constituents and research into these problems within the next few years should prove particularly rewarding. 
I acknowledge, with pleasure, the helpful advice and criticism of Dr S J. Rowland.

\section{REFERENCES}

Balch, C. C., Balch, D. A., Bartlett, S., Bartrum, M. P., Johnson, V. W., Rowland, S. J. \& Turner, J. (1955). F. Dairy Res. 22, 270.

Balch, C. C., Balch, D. A., Bartlett, S., Cox, C. P. \& Rowland, S. J. (1952). 7. Dairy Res. 19, 39. Balch, C. C., Balch, D. A., Bartlett, S., Cox, C. P., Rowland, S. J. \& Turner, J. (1954). F. Dairy Res. 2I, I65.

Balch, C. C., Balch, D. A., Bartlett, S., Hosking, Z. D., Johnson, V. W., Rowland, S. J. \& Turner, J. (1955). F. Dairy Res. 22, Io.

Balch, C. C., Johnson, V. W. \& Turner, I. A. (1955). Rep. Nat. Inst. Dairy. Reading, p. 40.

Balch, D. A. \& Rowland, S. J. (1957). Brit. F. Nutr. I1, 288.

Barry, J. M. (1958). Proc. roy. Soc. B, 149, 380.

Burt, A. W. A. (1957). Dairy Sci. Abstr. 19, 436 .

Folley, S. J. (1956). The Physiology and Biochemistry of Lactation. Edinburgh and London: Oliver and Boyd.

Glascock, R. F. (1958). Proc. roy. Soc. B, 149, 402.

Hilditch, T. P. (1956). The Chemical Constitution of Natural Fats, 3 rd ed. London: Chapman and Hall.

Knodt, C. B. (I94I). F. Dairy Sci. 24, 501.

Mann, A. I. \& Shaw, J. C. (r947). F. Dairy Sci. 30, I 83.

Masson, M. J. (195I). Research, 4, 73.

Malpress, F. H. (1945-6), Proc. R. Soc. Med. 39, 805.

McClymont, G. L. (1950). Aust. vet. F. 26, I I I.

McClymont, G. L. (1951a). Aust. F. agric. Res. 2, 92.

McClymont, G. L. (195Ib). Aust. F. agric. Res. 2, 158.

Pennington, R. J. (1957). Biochem. F. 65, 534.

Phillipson, A. T. (1952). Brit. F. Nutr. 6, 190.

Powell, E. B. (1938). Proc. Amer. Soc. Anim. Prod. p. 40.

Powell, E. B. (1939). F. Dairy Sci. 22, 453 .

Powell, E. B. (r94I). F. Dairy Sci. 24, 504.

Riddet, W., Campbell, I. L., McDowall, F. H. \& Cox, G. A. (x94I-2a). N.Z. F. Sci. Tech. 23, 80A. Riddet, W., Campbell, I. L., McDowall, F. H. \& Cox, G. A. (194I-2b). N.Z. F. Sci. Tech. 23, 99A. Rook, J. A. F. (1953). Proc. Nutr. Soc. 12, viii.

Rook, J. A. F. \& Rowland, S. J. (I959). Int. Dairy Congr. xv. London, I, 204.

Rowland, S. J. (1946). Dairy Ind. 11, 656.

Smith, J. A. B. \& Dastur, N. N. (1938), Biochem. J. 32, r868.

Tyznik, W. \& Allen, N. N. (1951). F. Dairy Sci. 34, 493.

Vallance, W. S. \& McClymont, G. L. (1959). Nature, Lond., 183, 466.

Van Soest, P. J., Allen, N. N. \& Maki, L. R. (1954). F. Dairy Sci. 37, 660.

Woodman, H. E. (1957). Bull. Minist. Agric., Lond., no. 48, 14th ed. p. 5 I.

\section{Some aspects of rumen ciliate protozoa}

\section{By J. Margaret Eadie, Rowett Research Institute, Bucksburn, Aberdeen}

The modern incentive for study of the rumen ciliates in relation to rumen function is not that the basic nature of their association with the ruminant is clearly understood but rather because of the one justified generalization: that certain species of ciliate have been found in the rumen of all normal adult ruminants so far examined. A study of their properties should therefore lead to a better understanding of the rumen as a whole. The comprehensive reviews of Hungate (r955) and Oxford (I955) cover the earlier work. I shall endeavour to discuss some of the more recent approaches to the subject. 